\title{
PRECLINICAL ALTERATIONS OF ORAL EPITHELIAL CELLS IN CONTACT WITH ORTHODONTIC APPLIANCES
}

\author{
Elcy Pinto de Arruda ${ }^{a}$, Paula Cristina Trevilatto ${ }^{a}$, Elisa Souza Camargo ${ }^{\text {a }}$, \\ Iverson Ernani Cogo Woyceichoski ${ }^{\mathrm{a}}$, Maria Angela Naval Machado ${ }^{\mathrm{b}}$, Iran Vieira ${ }^{\mathrm{b}}$, \\ Antonio Adilson Soares de Lima ${ }^{\text {b* }}$
}

\begin{abstract}
a Department of Stomatology, School of Dentistry, Pontificia Universidade Catolica do Parana-PUCPR, Curitiba-PR, Brazil
${ }^{b}$ Department of Stomatology, School of Dentistry, Universidade Federal do Parana-UFPR, Curitiba-PR, Brazil

E-mail:aas.lima@ufpr.br
\end{abstract}

Received: February 3, 2011; Accepted: July 14, 2011

Key words: Oral epithelium/Exfoliative cytology/Brackets/Orthodontic band/Orthodontic appliance

Aim. This study evaluated the behavior of oral epithelial cells in contact with orthodontic appliances.

Methods. Oral epithelial cells of clinically normal buccal mucosa were obtained by liquid-based exfoliative cytology from 22 orthodontic patients. The following regions were evaluated: a) oral mucosa exposed to friction from orthodontic brackets; $b$ ) oral mucosa exposed to friction from the tube on the orthodontic band, and c) oral mucosa not exposed to friction (control area). Nuclear (NA) and cytoplasmic (CA) areas and NA/CA ratio were assessed by an image analysis system. Cell morphology and cellularity were also analyzed by Papanicolaou technique.

Results. The NA of the cells in contact with orthodontic brackets and bands were smaller than the control area. Cells in contact with the brackets showed the greatest reduction in CA in comparison with the cells subjected to friction from the tube, and the control group. Smears classified as type I predominated in all regions analyzed, although type II were predominant, together with superficial epithelial cells, mainly in the oral mucosa in contact with the band tube.

Conclusion. Preclinical alterations in the epithelial cells of oral mucosa, caused by orthodontic appliances, are reduction in NA, increase in cell keratinization and inflammatory features, especially in the band tube area.

\section{INTRODUCTION}

The oral mucosa is a mucous membrane that covers all structures inside the oral cavity except the teeth. Its structure varies depending on its location in the oral cavity and the function of the corresponding area ${ }^{1}$. The integrity of mucosa membrane is fundamental for the maintenance of oral health ${ }^{2}$. However, epithelial cells may change due to oral diseases, infections, traumatic agents or metabolic conditions, resulting in several clinical alterations and neoplasms ${ }^{3}$.

Most oral lesions are a reaction to local irritation, and are not a cause for concern. Rarely, they can be an early sign of more serious mouth conditions. In general, the most common oral lesions are associated with trauma ${ }^{4,5}$. An ill-fitting, rough, or broken orthodontic appliance, a removable dental prosthesis, or a fractured or irregular tooth surface can affect the adjacent soft tissues. Acute or intense trauma to the oral tissues can induce changes with a deeper involvement, and produce hematoma, erosion, or ulcer. When a trauma agent acts slowly or is applied in low intensity on the tissue, the result is a reactive lesion ${ }^{6}$.

During orthodontic treatment, pain and discomfort in the oral mucosa can be experienced as a result of trauma from the appliances caused by increased friction between mucosal tissue and the surface of the brackets and tubes ${ }^{7}$. Proliferative and ulcerated lesions can appear as a result of this insult. Meanwhile, epidemiologic and histologi- cal studies on this issue in orthodontics patients are very scarce. The aim of this study, therefore, was to assess the effect of the friction of brackets and tubes on the epithelial cells of clinically normal oral mucosa using cytological and cytomorphometrical techniques.

\section{MATERIAL AND METHODS}

The experimental protocol of the present study was approved by Ethics Committee on Human Research at Pontifícia Universidade Católica do Paraná - PUCPR (Protocol number: CEP 604).

\section{Subjects}

This study was carried out with 22 male subjects aged 17 to 42 years from a private dental clinic. All the subjects were using a fixed orthodontic appliance for two years without any history of oral lesions. These patients were treated by straight wire technique. The fixed appliances consisted of an average of 4 to 8 bands and 20 bonded brackets. Metallic brackets and tubes (Morelli ${ }^{\mathrm{TM}}$, straight wire Roth, slot .22 x .030) were produced by Morelli Ortodontia (Morelli Dental Company, Sorocaba/SP, Brazil). The arch wires used in this study were a chromenickel alloy (Morelli Dental Company ${ }^{\mathrm{TM}}$, Sorocaba/SP, Brazil). Subjects did not consume any type of drug prior to the study include alcohol and tobacco. A full blood 
count was taken to exclude anemia for each patient. Name, age, occupation, and relevant medical history were recorded.

\section{Cells collection}

Oral exfoliated cells of the clinically normal buccal mucous membrane were obtained by liquid-based exfoliative cytology. Initially, the mouth was rinsed with water to remove excess of debris and bacteria within the oral cavity. Smears were collected from three distinct regions:

Region 1 - Oral mucosa subject to friction from orthodontic brackets;

Region 2 - Oral mucosa subject to friction from the tube on the orthodontic band;

Region 3 - Oral mucosa under no friction, bottom area of the vestibule (control area).

The squamous epithelial cells were collected using cytobrush and kit $\mathrm{UCM}^{\mathrm{TM}}$ (Universal Collection Medium of DNA-Citoliq System, Digene Brazil).

\section{Cytological preparations}

An aliquot of $200 \mu \mathrm{l}$ of UCM was filtered through filtrogene polycarbonate membrane filters ${ }^{\mathrm{TM}}$ (Digene, Brazil), pore size $5 \mu \mathrm{m}$, diameter $25 \mathrm{~mm}$ placed in prepgene press $^{\mathrm{TM}}$ (Digene, Brazil) attached to glass slides. Glass slides were immediately fixed in absolute alcohol for 20 min. Smears were then stained with routine Papanicolaou stain.

\section{Cytomorphometrical analysis}

Each slide was assessed using the light microscopy by binocular Olympus BX50 microscopy ${ }^{\text {TM }}$ (Olympus, Japan). Fifty randomly selected cells were measured in a stepwise fashion. Cell images were captured for digitalizing by Sony CCD Iris Color Video Camera ${ }^{\mathrm{TM}}$ (Sony Model DXC-107A, Japan) at X400 magnification. The nuclear (NA) and cytoplasmic (CA) areas were obtained by drawing around areas the nuclear and cell boundaries using the digitizer cursor and measuring mode of Image-Pro Plus ${ }^{\mathrm{TM}}$ image analysis system (Media Cybernetics, Silver Spring MD, USA), version 4.5.029 for Windows 98/NR/2000.

\section{Cytomorphological analysis}

Each slide was assessed using the light microscopy by binocular Olympus BX50 microscopy ${ }^{\mathrm{TM}}$ (Olympus, Japan). All cellular features were coded according to Papanicolaou system classification: normal, inflammatory, reactive, degenerative and neoplasic conditions of oral epithelial cells. The type of predominant cell (cellularity) in each smear was analyzed by counting.

\section{Statistical analysis}

Numerical data were analyzed using normality test of Kolmogorov-Smirnov, homogeneity of variance of Levene, multiple comparisons using ANOVA, Tukey, and GamesHowell. The Chi-square test was used to test if there was a relation between the predominance of cell and regions. Differences were considered statistically significant when $p<0.05$. All data were tabulated and statistical tests were performed with SPSS for Windows 13.0 (SPSS Inc., Chicago, Illinois, USA).

\section{RESULTS}

A total of 3,300 epithelial cells were assessed. There was statistically significant difference between the mean values of the nuclear area according to the regions. The nuclear area of the cells in the mucosal region under friction with orthodontic brackets (region 1) and tube on the orthodontic band (region 2) was diminished in comparison with the control (region 3 ). This reduction was statistically significant $(\mathrm{p}<0.01)$. Oral epithelial cells that came into contact with the mandibular incisor brackets showed the largest reduction in the nuclear area, when compared with the other regions assessed. However, this reduction was not statistically significant when compared with those in contact with the band tube $(p>0.05)$, as shown in (Table 1).

Mean values in the cytoplasmic area showed statistically significant difference according to the regions $(p<0.01)$. The mucosal region in contact with the mandibular incisor brackets showed the greatest reduction in area in comparison with the cells under friction from the tube, and the control group. However, the cytoplasmic area in the region 2 showed an increase in comparison to the control area. Nevertheless, this increase was not statistically significant ( $p>0.05$ ) (Table 1).

There was no statistically significant difference in the mean values of the NA/CA ratio between the regions ( $p>0.05$ ). The mean values and their respective standard deviations for all the studied variables are shown in (Table 1).

There was a predominance of class I smears in all regions analyzed. The number of class II type smears (inflammatory) was higher in the mucosal area in contact with the band tube. The number of class II type smears observed in this region was more twice as high as that of the control region, although this difference is not statistically significant (Table 2). A predominance of nucleated cells of the superficial layer in the oral mucosa region in contact with the band tube was found compared to the other two regions (Table 3 ).

\section{DISCUSSION}

This research investigated 3,300 oral epithelial cells from patients undergoing orthodontic treatment by means of cytological and cytomorphometrical analysis. The results demonstrated that the NA of the cells in contact with brackets bonded to the incisors and the band tube diminished in comparison with the control. In addition, the mucosal region in contact with the mandibular incisor brackets showed the greatest reduction in CA in comparison with the cells under friction from the tube, and the control group. Although there was no alteration in the $\mathrm{NA} / \mathrm{CA}$ ratio in regions 1 and 2 in comparison with the control, the cells presented some preclinical histological 
Table 1. Cytological measurements in epithelial cells of different oral regions from orthodontics patients.

\begin{tabular}{|l|c|c|c|c|}
\hline $\begin{array}{c}\text { Groups } \\
\text { Variable }\end{array}$ & $\begin{array}{c}\text { Bracket region } \\
\text { Mean } \pm \text { SD }\end{array}$ & $\begin{array}{c}\text { Tube region } \\
\text { Mean } \pm \text { SD }\end{array}$ & $\begin{array}{c}\text { Control region } \\
\text { Mean } \pm \text { SD }\end{array}$ & $P$ value \\
\hline $\mathrm{NA}^{*}$ & $52.39 \mu \mathrm{m}^{2} \pm 16.86$ & $53.09 \mu \mathrm{m}^{2} \pm 18.32$ & $63.06 \mu \mathrm{m}^{2} \pm 19.46$ & $0.0000^{\Psi}$ \\
\hline $\mathrm{CA}^{* *}$ & $1668.71 \mu \mathrm{m}^{2} \pm 578.81$ & $1884.85 \mu \mathrm{m}^{2} \pm 675.03$ & $1810.66 \mu \mathrm{m}^{2} \pm 663.55$ & $0.0001^{\Psi}$ \\
\hline $\mathrm{NA} / \mathrm{CA}^{* * *}$ & $0.03 \pm 0.06$ & $0.03 \pm 0.06$ & $0.03 \pm 0.01$ & 0.3230 \\
\hline
\end{tabular}

*NA: nuclear area; ${ }^{* *}$ CA: cytoplasmic area; ${ }^{* * * N A}$ /CA: nuclear/cytoplasmic area ratio; ${ }^{*}$ Statistics difference $(\mathrm{P}<.01)$

Table 2. Characterization of smears by Papanicolaou system classification.

\begin{tabular}{|c|c|c|c|c|c|c|}
\hline $\begin{array}{c}\text { Papanicolaou } \\
\text { classification }\end{array}$ & $\begin{array}{c}\text { Bracket } \\
\mathrm{n}\end{array}$ & $\begin{array}{c}\text { Region } \\
\%\end{array}$ & $\begin{array}{c}\text { Tube } \\
\mathrm{n}\end{array}$ & $\begin{array}{c}\text { Region } \\
\%\end{array}$ & $\begin{array}{c}\text { Control } \\
\mathrm{n}\end{array}$ & $\begin{array}{c}\text { Region } \\
\%\end{array}$ \\
\hline Class 1 & 19 & 86.3 & 17 & 77.2 & 20 & 90.9 \\
\hline Class 2 & 3 & 13.6 & 5 & 22.7 & 2 & 9.0 \\
\hline Class 3 & 0 & 0 & 0 & 0 & 0 & 0 \\
\hline Class 4 & 0 & 0 & 0 & 0 & 0 & 0 \\
\hline Class 5 & 0 & 0 & 0 & 0 & 0 & 0 \\
\hline Total & 22 & 100 & 22 & 100 & 22 & 100 \\
\hline
\end{tabular}

Table 3. Type of predominant cell in oral smears of different regions from orthodontics patients.

\begin{tabular}{|c|c|c|c|c|c|}
\hline Region & $\begin{array}{c}\text { Enucleated } \\
\text { superficial layer } \\
\text { cells } \\
\text { n } \%\end{array}$ & $\begin{array}{l}\text { Nucleated } \\
\text { superficial } \\
\text { layer cells } \\
\text { n } \%\end{array}$ & $\begin{array}{c}\text { Intermediated } \\
\text { layer cells } \\
\text { n } \%\end{array}$ & $\begin{array}{l}\text { Basal layer } \\
\text { cells } \\
\text { n } \%\end{array}$ & Total \\
\hline Bracket & $\begin{array}{ll}0 & 0\end{array}$ & 1150 & 1150 & $\begin{array}{ll}0 & 0\end{array}$ & 22 \\
\hline Tube & 0 & 1986 & $\begin{array}{ll}03 & 14\end{array}$ & 0 & 22 \\
\hline Control & 0 & $10 \quad 45$ & $12 \quad 55$ & 0 & 22 \\
\hline Total & 0 & $40 \quad 60$ & $26 \quad 40$ & 0 & 66 \\
\hline
\end{tabular}

Chi-square test: $\mathrm{P}$ value $=0.0097$

reaction to the presence or the friction from the appliance.

The contact of metal and ceramic brackets in the oral cavity induces cellular alterations. In 2009, Pereira et al. ${ }^{8}$ observed that the placement of brackets in the buccal cavity caused decrease of the nucleus, increase in the cytoplasm, and a lower nuclear/cytoplasmic ratio of oral epithelial cells that were in contact with the brackets. Similarly, the results of our study demonstrated that metallic brackets can irritate the epithelial cells and induce changes, mainly, to the nucleus.

Measurements of NA and CA have been used as important parameters for detecting alterations in the epithelial tissues ${ }^{9-14}$. In our study, two situations were present: i) a reduction in both NA and CA (region 1), and ii) a reduction only in the NA (region 2). In relation to the reduction in both, NA and CA (region 1), histologically, this cellular reaction may be recognized as atrophy. Atrophy represents an adaptive response that allows cells to suspend their differentiated functions, reducing the energy requirements to a minimum. This process presents various causes, among them: diminished blood supply, inadequate nutrition, hypoxia, and compression ${ }^{6}$. Due to those effects, cell atrophy may progress to the point where the cells are injured and $\mathrm{die}^{15}$. In the region 2 , besides the NA decrease, the reduction in the CA might be in progress, maybe by the fact brackets are more aggressive physical agents to cause chronic tissue irritation. Thus, these results suggest that mechanical friction might also represent a potential cause for alterations in NA and CA.

With regard to the morphological analysis, the results showed that there was a predominance of class I smears in 
all regions analyzed. The number of class II type smears (inflammatory) was higher in the mucosa region in contact with the band tube. Although there was more than twice the prevalence of inflammatory cells than in the control region, the number of class II smears is small in all the three regions, and this could solely represent the inflammatory response of the mucosa to the biological and physical stimuli inside the mouth.

The smears obtained by exfoliative cytology generally exhibit a scarcity of basal layer cells when the oral epithelium is intact. This indicates that this technique does not remove cells from the deeper layers of the epithelium, but the small number of these cells in the smears does not necessarily reflect a limitation of this technique ${ }^{11}$. On the other hand, Silverman et al. ${ }^{16}$ reported that in the oral mucosa, there are predominantly intermediate layer cells. In the area in contact with the mandibular incisor brackets, and in the bottom area of the vestibule (control region), there was a balance between the superficial and intermediate layer cells. The results obtained in the quantitative assessment showed a predominance of cells of the superficial layer from the oral mucosa subject to friction with the band tube. Possibly, this occurs because there is thickening of the cornea layer and, consequently, greater predominance of superficial cells. Kwon et al. ${ }^{15}$ also found that chronic irritation produces a greater number of superficial layer cells, due to keratinization of the mucosa, although in that study the irritation was caused by tobacco and not physical trauma. Zimmermann and Zimmermann ${ }^{17}$ also found that oral mucosa smears from smokers showed a larger number of keratinized cells. Pereira et al. ${ }^{8}$ observed an increase in the number of cells in the corneum stratum of the epithelium in contact with metallic brackets.

Clinically, some patients under orthodontic treatment might develop small white patches in the oral mucosa in contact with brackets and bands ${ }^{18}$. Those white patches are a natural reaction of the oral mucosa to the physical trauma induced by the appliance. This condition is termed frictional keratosis. Acanthosis (an augment in the thickness of the spinous layer) and hyperkeratosis (an augment in the thickness of the corneous layer), usually orthokeratosis, are the hallmarks of frictional keratosis. The cells of the spinous layer often demonstrate intraepithelial edema and occasional vacuolated cells with pyknotic nuclei. According to Regezi and Sciubba ${ }^{19}$, traumatic agents of a mechanical nature may induce frictional keratosis. In the present study, white patches were not observed. Besides, none of the individuals had ulcerations in the mucosa resulting from friction with the orthodontic appliance.

Several studies have reported the effect of different types of diseases and aggressive agents on oral mucosa, such as alcohol, and tobacco ${ }^{10,12,20-25}$. However, studies reporting physical trauma associated to use of orthodontic appliances are still scarce ${ }^{8}$. Although biopsy is still the gold-standard technique for a precise diagnosis, oral cytological examination is non-invasive, very sensitive for detection of cell alteration ${ }^{26}$. Thus, liquid-based cytology may be a useful tool for the assessment of cellular changes in apparently normal mucosa ${ }^{27}$.
Considering that i) brackets and band tubes are aggressive physical agents that have the potential to cause damage to oral soft tissues, and ii) the mucosal area in contact with the brackets and the band tube are similar histologically, one may conclude that the augmentation of cells from the superficial layer, and smears Class II type, found in the mucosal area in contact with the band tube may be explained by the fact that the area under friction is larger in contact with the tube. Moreover, although less probable, difficulty in terms of hygiene access could not be discharged.

Fixed orthodontic appliances usually include brackets, bands, and arch wires made of stainless steel, nickel-titanium, or nickel-cobalt alloys, and these can release metal ions. Although the metal devices used in orthodontic treatments are manufactured to be highly resistance to corrosion, they may still suffer some localized corrosion resulting from the oral cavity conditions. The corrosion causes the release of metals from the alloys used for their manufacture. In this context, some studies have shown that contact of orthodontic appliances with the oral mucosa is unable to cause cytotoxicity or genotoxicity ${ }^{28-30}$.

White patches and ulcerations reflect extensive tissue injury upon orthodontic treatment. Thus, periodic evaluations by means of liquid-based exfoliative cytology could represent a precious diagnostic tool to evaluate cell damage before clinical signs appear.

Our cytological findings represent evidence for preclinical alterations. Orthodontic appliances should be fabricated to cause the least "disturbance" in the epithelium in contact.

\section{CONCLUSIONS}

Based on the findings of this study, it can be suggested that the main preclinical alterations in the epithelial cells of oral mucosa, caused by orthodontic appliances, are reduction of the nuclear area, cell keratinization and inflammatory features, especially in the band tube area. In this context, liquid-based exfoliative cytology may represent a useful preclinical tool to evaluate cell damage.

\section{REFERENCES}

1. Nanci A. Ten Cate's oral histology: Development, structure, and function. $7^{\text {th }}$ ed. Mosby, 2007.

2. Wolff A, Ship JA, Tylenda CA, Fox PC, Baum BJ. Oral mucosal appearance is unchanged in healthy, different-aged persons. Oral Surg Oral Med Oral Pathol 1991;71:569-72.

3. Sognnaes RF, Albright JT. Electron microscopic study of the epithelial lining of the human oral mucosa. Oral Surg Oral Med Oral Pathol 1958;11:62-73.

4. Schulman JD, Beach MM, Rivera-Hidalgo F. The prevalence of oral mucosal lesions in U.S. adults: data from the Third National Health and Nutrition Examination Survey, 1988-1994. J Am Dent Assoc 2004;135(9):1279-86.

5. Schulman JD. Prevalence of oral mucosal lesions in children and youths in the USA. Int J Paediatr Dent 2005;15(2):89-97.

6. Cotran RS, Kumar V, Collins T. Robbins pathologic basis of disease. Philadelphia: W.B. Saunders Company, 1999. 
7. Kluemper GT, Hiser DG, Rayens MK, Jay MJ. Efficacy of a wax containing benzocaine in the relief of oral mucosal pain caused by orthodontic appliances. Am J Orthod Dentofacial Orthop 2002;122(4):359-65.

8. Pereira BR, Tanaka OM, Lima AA, Guariza-Filho O, Maruo H, Camargo ES. Metal and ceramic bracket effects on human buccal mucosa epithelial cells. Angle Orthod. 2009;79(2):373-9.

9. Cowpe JG, Longmore RB, Green MW. Quantitative exfoliative cytology of normal oral squames: an age, site and sex-related survey. J R Soc Med 1985;78(12):995-1004.

10. Ogden GR, Cowpe JG, Green MW. Quantitative exfoliative cytology of normal buccal mucosa: effect of smoking. J Oral Pathol Med 1990;19(2):53-5.

11. Ogden GR, Cowpe JG, Wight AJ. Oral exfoliative cytology: review of methods of assessment. J Oral Pathol Med 1997;26(5):201-5.

12. Ramaesh T, Mendis BRRN, Ratnatunga N, Thattil RO. Cytomorphometric analysis of squames obtained from normal oral mucosa and lesions of oral leukoplakia and squamous cell carcinoma. J Oral Pathol Med 1998;27(2):83-6.

13. Diniz-Freitas M, Garcia-Garcia A, Crespo-Abelleira A, MartinsCarneiro JL, Gandara-Rey JM. Applications of exfoliative cytology in the diagnosis of oral cancer. Med Oral 2004;9(4):355-61.

14. Mehrotra R, Gupta A, Singh M, Ibrahim R. Application of cytology and molecular biology in diagnosing premalignant or malignant oral lesions. Mol Cancer 2006;5(11):5-11.

15. Kwon OS, Chung JH, Cho KH, Suh DH, Park KC, Kim KH, Eun He. Nicotine-enhanced epithelial differentiation in reconstructed human oral mucosa in vitro. Skin Pharmacol Appl Skin Physiol 1999;12(4):227-34.

16. Silverman SJR, Becks H, Farber SM. The diagnostic value of intraoral cytology. J Dent Res 1958;37(2):195-205.

17. Zimmermann ER, Zimmermann AL. Effects of race, age, smoking habits, oral and systemic disease on oral exfoliative cytology. J Dent Res 1965;44(4):627-31.

18. Ozcelik O, Haytac MC, Akkaya M. Iatrogenic trauma to oral tissues. J Periodontol 2005;76(10):1793-7.
19. Regezi JA, Sciubba JJ. Oral pathology: clinical pathologic correlations. 3ed. Philadelphia: W. B. Saunders Company, 1999.

20. Ogden GR, Wight AJ, Cowpe JG. Quantitative oral exfoliative cytology. Effect of alcohol on normal buccal mucosa. Anal Quant Cytol Histol 1999;21(2):126-30.

21. Ogden GR, Wight AJ, Rice P. Effect of alcohol on the oral mucosa assessed by quantitative cytomorphometry. J Oral Pathol Med 1999;28(5):216-20.

22. Ramaesh T, Mendis BR, Ratnatunga N, Thattil RO. The effect of tobacco smoking and of betel chewing with tobacco on the buccal mucosa: a cytomorphometric analysis. J Oral Pathol Med 1999;28(9):385-8.

23. Alberti S, Spadella CT, Francischone TR, Assis GF, Cestari TM, Taveira LA. Exfoliative cytology of the oral mucosa in type II diabetic patients: morphology and cytomorphometry. J Oral Pathol Med 2003;32: 538-43.

24. Einstein TB, Sivapathasundharam B. Cytomorphometric analysis of the buccal mucosa of tobacco users. Indian J Dent Res 2005;16(2):42-6.

25. Pavanello MB, Prado FB, Balducci I, Brandao AA. Cytologic analysis of alterations induced by smoking and by alcohol consumption. Acta Cytol 2006;50(4):435-40.

26. Jones AC, Migliorati CA, Stewart CM. Oral cytology: indications, contraindications, and technique. Gen Dent 1995;43(1):74-7.

27. Alves VAF, Castelo A, Filho AL, Vianna MR, Taromaru E, Namiyama G, Lorincz A, Dores GBD. Performance of the DNACitoliq liquid-based cytology system compared with conventional smears. Cytopathology 2006,17:86-93.

28. Wever DJ, Veldhuizen AG, Sanders MM, Schakenraad JM, van Horn JR. Cytotoxic, allergic and genotoxic activity of a nickeltitanium alloy. Biomaterials. 1997;18(16):1115-20.

29. Montanaro L, Cervellati M, Campoccia D, Prati C, Breschi L, Arciola CR. No genotoxicity of a new nickel-free stainless steel. Int J Artif Organs 2005;28(1):58-65.

30. Angelieri F, Carlin V, Martins RA, Ribeiro DA. Biomonitoring of mutagenicity and cytotoxicity in patients undergoing fixed orthodontic therapy. Am J Orthod Dentofacial Orthop. 2011;139(4 Suppl):e399-404. 
